\title{
THE FINANCING STRUCTURE OF POLISH NON-FINANCIAL ENTERPRISES IN THE FACE OF FINANCIALISATION CHALLENGES
}

\author{
Alina RYDZEWSKA \\ Silesian University of Technology, Faculty of Organization and Management, Institute of Economy and Finance, \\ Poland; Alina.Rydzewska@ polsl.pl, ORCID: 0000-0002-4535-3585
}

Purpose: The aim of this article was to examine whether financialization phenomena affected the financing structure of non-financial enterprises operating in Poland. Changes in the financing structure in the era of financialization are manifested by the growing share of debt (foreign capital), the increase in the importance of securities while reducing the share of credit as sources of financing business activities and the growing involvement of (passive) derivatives. Design/methodology/approach: The analysis was conducted on the basis of indicators identifying the share of foreign capital in total liabilities, the structure of passive financial instruments and the structure of passive derivatives.

Findings: Based on the empirical analysis, it was found that the phenomenon of the financing structure of financialization is not noticeable on the example of the surveyed business entities. The share of foreign capital in total liabilities of enterprises in 2010-2018 was around 0.5. In the financial assessment, it is the optimal financing structure.

Research limitations/implications: Financialization is a developing phenomenon. The presented research covered the years 2010-2018, therefore research on the discussed issue should be continued.

Originality/value: The originality of the article is associated with the analysis of the increase in the importance of debt in financing operations in relation to enterprises in Poland, including by industry.

Keywords: financing structure, financialization, analysis of financial statements

Category of the paper: research paper

\section{Introduction}

Financialization is a phenomenon that challenges contemporary theoreticians and practitioners of social sciences. Financialization is a complex interdisciplinary concept: economic, sociological, political, psychological and ethical. What the presented areas have in common is a particular and growing role of the financial sphere and the financial criteria in the 
functioning of the economy and in the economic and social life (Stockhammer, 2004, pp. 719-741).

Financialization in economic terms is associated with the growing importance of financial institutions and financial markets in economic life and their increasing impact on the activities of economic entities. One of the most important manifestations of this phenomenon is the increase in the leverage rate of economic activity of non-financial enterprises (Ratajczak, 2012, p. 291). It is associated with changes in the selection of financing sources, which is manifested in changes in the financing structure.

The phenomenon of leveraging economic activity is conducive to changes in the environment. Transformations on financial markets have enabled access to financial instruments for a larger group of companies. An important element of changes in the global financial system was the extension of the offer of new instruments available on the financial market. In addition, the decrease in real interest rates has contributed to the reduction of the cost of obtaining foreign capital, which encouraged business entities to use foreign sources of financing. On the other hand, the number of enterprises raising capital from financial markets and the growing role of institutional investors has led to transformations in the sphere of management and ownership, especially of large enterprises. The companies, assessed from the perspective of investors (shareholders), are focused on generating short-term profit. So managers apply leverage and use financial instruments to generate profit to meet shareholder expectations.

The aim of this article was to examine whether financialization phenomena affected the financing structure of non-financial enterprises operating in Poland. Changes in the financing structure in the era of financialization are manifested in the growing share of debt (foreign capital). In addition, the development of capital markets has increased the importance of securities, which could have resulted in a decrease in the share of credit as sources of financing business activities. The growing financial commitment of (passive) derivatives is also a characteristic of enterprise financialization (Ratajczak, 2012, p. 291).

In this study, the method of analysing indicators identifying the structure of financing with equity and foreign capital and the structure of passive financial instruments was used for research. For this purpose, the financial statements of non-financial enterprises published by the Statistics Poland (GUS) for the years 2010-2018 were used, considering the classification of data according to the industry. 


\section{The impact of financialization on the financing structure of enterprises}

The growing financial sector in the economy related to financialization has caused changes in the sphere of management and ownership of business entities. Companies issuing securities on financial markets are assessed from the investors' perspective (Nawrocki, Szwajca, 2016, pp. 165-171). When shares are issued, the shareholders become their owners. Whereas the growing role of financial institutions conditioned the growing importance of institutional investors. Owners-shareholders from financial markets treat their investments as one of the periodic and alternative forms of investing capital (Rydzewska, 2016, p. 55). Their activities, especially institutional owners, are associated with the so-called impatient capital, looking for the possibility of obtaining extraordinary profits in the short term (Williams, 2000, pp. 1-12). The quality of management of joint-stock companies is assessed from the perspective of the financial markets. The information flowing from them is the basis for comparing the profitability of investment directions. To assess the effectiveness of allocated capital, shareholders use measures that take into account short-term profitability. One of the most commonly used is the ROE (return on equity) (Dembinski, 2011, p. 148; Froud et al., 2000). ROE is a simple measure illustrating the profitability of equity (e.g. invested by shareholders).

Considering the possibilities of creating the ROE indicator, two paths stand out. The first is to influence the capital structure, the second is to maximize profit. Focusing on the selection of sources of capital, it is associated with the growing importance of various forms of debt as a source of financing an enterprise (Crotty, 2005, p. 89). In the era of financialization, external sources of financing are complemented by internal sources, not the other way around (Milberg, 2009, pp. 420-451). Hence, some enterprises, in order to change the capital structure, use techniques related to the repurchasing (redemption) of their own shares. Other business entities, by using debt to finance operations, are trying to minimise the need for equity. In this way, they can increase the ROE level without changing profit levels. It should be noted, however, that the conditions for financial leverage must be met, so the average profitability of capital used (including debt) must be higher than the interest rate of debt and the conviction of debtors with limited financial risk. The scale of leverage in recent years has been favoured by low-interest rates. And so, for example, if the annual EURIBOR in 2001 was at the level of $4.8 \%$, in 2005 it was $2 \%$, it increased during the crisis in 2008 to the level of $4.26 \%$, after which in 2010 it fell to $1.94 \%$ and is systematically falling. This year it reached the level of - (minus) $0.286 \%$ (http://www.euribor-rates.eu/euribor-rate-12-months).

As the economy developed financially, access to capital markets was facilitated. Through the development of alternative markets and the wider availability of various types of financial debt instruments, their importance in financing business entities has increased. And so, for example, the value of issues of debt securities of non-financial enterprises in 2001 amounted to USD 837.7 billion, in 2005 to USD 1292.6 billion, in 2010 to USD 1902 billion, and in 2017 
to USD 3674.5 billion. (https://stats.bis.org/statx/srs/table/f1.2?p=20053\&c=). The increase in the dynamics of issuing debt securities of the non-financial sector meant that some say as a result of finalisation, the role of banks has decreased in favour of the securities market and other financial intermediaries (Szczepankowski, 2017, pp. 155-172). This does not mean that the importance of banks in the financial system has been limited. The scale of banks' activity in financing enterprises is still significant, in particular through an increase in credit lending using both traditional instruments and more complex forms of securitisation and the dissemination of financial innovations, especially derivatives (Jonek-Kowalska, Zieliński, 2017, pp. 1294-1304). Thus, the value of credit to the non-financial sector in 2001 was USD 59.810 trillion, in 2005 USD 87.435 trillion, in 2010 USD 136.234 trillion and in 2017 USD 177.739 trillion. (https://stats.bis.org/statx/srs/table/f1.2?p=20104\&c=).

The inflation of financial instruments, in particular derivatives, is considered one of the manifestations of financialization (Ratajczak, 2012, p. 291). Derivatives are financial assets, whose prices depend on changes in the prices of underlying instruments (shares, bonds, stock indices, exchange rates, interest rates etc.). The total nominal value of derivatives traded on the market in 1998 was USD 72 trillion, in 2008 USD 673 trillion, in 2013 over USD 700 trillion, while in 2018 USD 544 trillion (BIS, https://www.bis.org/statistics/about_derivatives_stats. $\mathrm{htm} ? \mathrm{~m}=6 \% 7 \mathrm{C} 32 \% 7 \mathrm{C} 639)$. In addition to the quantitative increase in the value of derivatives, their qualitative development followed (Rydzewska, 2019, pp. 27-28). Derivatives can be a source of financing in enterprise reporting. They create obligations of the enterprise to issue financial assets or to exchange the financial instrument with another company on unfavourable conditions (e.g. after taking into account commissions, bank fees, discounts, decrease in the value of the financial instrument).

\section{Signs of financialization in the structure of enterprise financing - research methodology}

According to the literature on the subject, to assess the financing structure of enterprises, indicators determining the share of equity in the balance sheet total or foreign capital in the balance sheet total are used (Sierpińska, Jachna, 2004, pp. 167-169). As the feature of financialization of enterprises is an increase in debt in financing business activity, in this study, the indicator of financing assets with foreign capital (liabilities and provisions for liabilities) was used.

The formula for this indicator is presented in Formula 1.

$\mathrm{FC} / \mathrm{TL}=\frac{\text { foreign } \text { capital }}{\text { total liabilities }}$ 
This indicator illustrates the extent to which the enterprise's assets are financed with the company's foreign capital. Generally, growth means greater use of foreign sources of financing, which, with unchanged net profit, has a positive effect on the ROE and possible effects of financial leverage. This is a characteristic trend for enterprises in the era of financialization.

The analysis of the structure of passive financial instruments (share in total liabilities) supplements the assessment of the impact of finalising processes on the structure of enterprise financing. Indicators for the Structure of Passive Financial Instruments (SPFI) were calculated in accordance with formula 2.

SPFI $=\frac{\text { financial instruments }(\text { liabilities })}{\text { total liabilities }} * 100 \%$

This indicator reflects the share of passive financial instruments (liabilities on financial instruments, financial leasing liabilities, as well as credits and loans to be paid) in the total liabilities. The growth of this indicator means an increase in financial instruments significance in financing the company's activities. The characteristic of financialization is the increase in the share of capital market instruments in the capital structure.

The characteristic of enterprise financialization is also the growing importance of derivatives in the operations of enterprises, including as sources of financing (liabilities). The formula for indicator of derivatives share in total liabilities is presented in formula 3.

$\mathrm{IDS}=\frac{\text { passive derivatives }}{\text { total liabilities }} * 100 \%$

The above indicator expresses the share of passive derivatives in total liabilities. Growth means the growing importance of derivatives as sources of financing. It should be noted that, depending on the type of instrument, records and presentation in the financial statements are of a different nature. For example, contracts (forward, future) result in the simultaneous creation of financial assets and financial liabilities. However, options are recorded in two ways. When options are issued, they are financial liabilities. In turn, the valuation of swap contracts for reporting purposes (at fair value) may be of positive value (resulting in the recognition of a financial asset) or negative value (resulting in the recognition of a financial liability) (Gmytrasiewicz, Karmańska, 2010, pp. 306-331).

\section{Empirical Analysis}

In order to examine whether the processes of finalisation have affected the structure of financing the activities of non-financial enterprises in Poland, the research method was used: an analysis of indicators built on the basis of financial statements published by the Statistics Poland for 2010-2018 (Financial instruments...). 
Analysing the indicator of the share of foreign capital in the total liabilities, it can be seen in relation to total enterprises, that in the examined period it was close to 0.5 (only in 2014 it fell to 0.43). This means that half of the non-financial enterprises in Poland use foreign capital to finance assets, which is associated with an optimal capital structure.

Considering the discussed indicator by sector, the highest share of foreign capital in the financing structure at the beginning of the examined period was noticeable in the industry "Professional, scientific and technical activities" and amounted to 0.88 , while in subsequent years it decreased and reached 0.32 in 2017. In the "Wholesale and retail trade" industry, the total FC/Total Liabilities ratio in 2010 was also high (0.83), after which it dropped to 0.59 in the following year and stabilised at this level. On the other hand, the "Construction" industry was characterised by a significant level of foreign sources of financing at a similar level of 0.69 throughout the entire examined period. However, the reverse trend was noticeable in the sector "Administrative and support service activities". In 2010, the total FC/Total Liabilities ratio was 0.23 , in subsequent years the amount grew, reaching the level 0,85 in the year 2018.

Table 1.

Indicator of the share of foreign capital in total liabilities (FC/Total liabilities) including sectors

\begin{tabular}{|l|r|r|r|r|r|r|r|r|r|}
\hline & $\mathbf{2 0 1 0}$ & $\mathbf{2 0 1 1}$ & $\mathbf{2 0 1 2}$ & $\mathbf{2 0 1 3}$ & $\mathbf{2 0 1 4}$ & $\mathbf{2 0 1 5}$ & $\mathbf{2 0 1 6}$ & $\mathbf{2 0 1 7}$ & $\mathbf{2 0 1 8}$ \\
\hline Total enterprises & 0.49 & 0.50 & 0.47 & 0.49 & 0.43 & 0.51 & 0.52 & 0.50 & 0.51 \\
\hline Manufacturing & 0.53 & 0.50 & 0.47 & 0.48 & 0.49 & 0.47 & 0.49 & 0.47 & 0.47 \\
\hline $\begin{array}{l}\text { Production and supply of } \\
\text { electricity, gas etc. }\end{array}$ & 0.24 & 0.37 & 0.39 & 0.35 & 0.39 & 0.43 & 0.55 & 0.42 & 0.44 \\
\hline $\begin{array}{l}\text { Water supply; sewerage, waste } \\
\text { management etc. }\end{array}$ & 0.48 & 0.48 & 0.06 & 0.50 & 0.50 & 0.47 & 0.46 & 0.47 & 0.47 \\
\hline Construction & 0.69 & 0.68 & 0.68 & 0.67 & 0.66 & 0.66 & 0.65 & 0.67 & 0.69 \\
\hline Wholesale and retail trade; & 0.83 & 0.56 & 0.55 & 0.58 & 0.58 & 0.57 & 0.58 & 0.56 & 0.59 \\
\hline Transport and storage & 0.36 & 0.37 & 0.46 & 0.66 & 0.69 & 0.67 & 0.68 & 0.66 & 0.66 \\
\hline Information and communication & 0.27 & 0.48 & 0.41 & 0.52 & $\begin{array}{r}\text { nota } \\
\text { data }\end{array}$ & 0.58 & 0.55 & 0.55 & 0.54 \\
\hline $\begin{array}{l}\text { Real estate activities } \\
\text { Professional, scientific and } \\
\text { technical activities }\end{array}$ & 0.34 & 0.31 & 0.27 & 0.38 & 0.23 & 0.41 & 0.35 & 0.25 & 0.27 \\
\hline $\begin{array}{l}\text { Administrative and support } \\
\text { service activities }\end{array}$ & 0.88 & 0.70 & 0.65 & 0.59 & 0.63 & 0.47 & 0.52 & 0.32 & 0.45 \\
\hline
\end{tabular}

Taking into account the indicator of the structure of passive financial instruments, an increase in the share of passive financial instruments in total non-financial enterprises can be seen. As shown in Table 2, in the years 2010-2013 this indicator was at the level of 10-14\%. However, since 2014, it has jumped to $20 \%$. The growth of the indicator is the result of credits and loans / financial lease used to fund the entities' activities. In turn, considering the importance of financial market instruments as sources of financing for non-financial enterprises, a slight increase in the share of liabilities due to issues of own bonds can be seen. In 2010, it was 3.56\%, and in $2015-6.8 \%$, reaching the highest level in the examined period. 
Despite the growing importance of securities in financing enterprises, their share is at a lower level compared to credit and loans.

Table 2.

Indicators of the structure of passive financial instruments

\begin{tabular}{|l|r|r|r|r|r|r|r|r|r|}
\hline & $\mathbf{2 0 1 0}$ & $\mathbf{2 0 1 1}$ & $\mathbf{2 0 1 2}$ & $\mathbf{2 0 1 3}$ & $\mathbf{2 0 1 4}$ & $\mathbf{2 0 1 5}$ & $\mathbf{2 0 1 6}$ & $\mathbf{2 0 1 7}$ & $\mathbf{2 0 1 8}$ \\
\hline $\begin{array}{l}\text { LIABILITIES - } \\
\text { FINANCIAL } \\
\text { INSTRUMENTS, incl.: }\end{array}$ & $14.16 \%$ & $10.23 \%$ & $14.12 \%$ & $13.67 \%$ & $19.32 \%$ & $21.79 \%$ & $22.35 \%$ & $22.1 \%$ & $25.3 \%$ \\
\hline $\begin{array}{l}\text { credits and loans, finance } \\
\text { leasing and other }\end{array}$ & $0.77 \%$ & $0.74 \%$ & $0.74 \%$ & $5.33 \%$ & $10.57 \%$ & $12.01 \%$ & $18.36 \%$ & $13.3 \%$ & $13.7 \%$ \\
\hline $\begin{array}{l}\text { liabilities due to the issuance } \\
\text { of own bonds }\end{array}$ & $3.56 \%$ & $2.50 \%$ & $5.19 \%$ & $5.38 \%$ & $5.73 \%$ & $6.80 \%$ & $0.55 \%$ & $5.0 \%$ & $4.4 \%$ \\
\hline liabilities due to derivatives & $0.93 \%$ & $0.97 \%$ & $0.59 \%$ & $0.29 \%$ & $0.62 \%$ & $0.53 \%$ & $0.45 \%$ & $0.4 \%$ & $0.5 \%$ \\
\hline other financial instruments & $9.23 \%$ & $6.45 \%$ & $7.59 \%$ & $2.67 \%$ & $2.40 \%$ & $2.45 \%$ & $2.98 \%$ & $3.4 \%$ & $6.7 \%$ \\
\hline \begin{tabular}{l} 
TOTAL LIABILITIES \\
\hline
\end{tabular} & $42.39 \%$ & $43.05 \%$ & $42.70 \%$ & $42.20 \%$ & $43.10 \%$ & $43.80 \%$ & $44.27 \%$ & $43.23 \%$ & $\begin{array}{r}51.26 \\
\%\end{array}$ \\
\hline
\end{tabular}

Table 3.

Indicators of the structure of passive derivatives

\begin{tabular}{|l|r|r|r|r|r|r|r|r|r|}
\hline & $\mathbf{2 0 1 0}$ & $\mathbf{2 0 1 1}$ & $\mathbf{2 0 1 2}$ & $\mathbf{2 0 1 3}$ & $\mathbf{2 0 1 4}$ & $\mathbf{2 0 1 5}$ & $\mathbf{2 0 1 6}$ & $\mathbf{2 0 1 7}$ & $\mathbf{2 0 1 8}$ \\
\hline PASSIVE & & & & & & & & & \\
DERIVATIVES & $0.9276 \%$ & $0.9677 \%$ & $0.5930 \%$ & $0.2853 \%$ & $0.6229 \%$ & $0.5329 \%$ & $0.4530 \%$ & $0.4185 \%$ & $0.5433 \%$ \\
\hline Forward contracts & $0.1099 \%$ & $0.2743 \%$ & $0.1843 \%$ & $0.1407 \%$ & $0.2631 \%$ & $0.3041 \%$ & $0.3117 \%$ & $0.3210 \%$ & $0.3684 \%$ \\
\hline Futures contracts & $0.0073 \%$ & $0.0044 \%$ & $0.0010 \%$ & $0.0017 \%$ & $0.0007 \%$ & $0.0047 \%$ & $0.0051 \%$ & $0.0201 \%$ & $0.0766 \%$ \\
\hline Options & $0.3745 \%$ & $0.1637 \%$ & $0.0478 \%$ & $0.0076 \%$ & $0.0202 \%$ & $0.0223 \%$ & $0.0325 \%$ & $0.0172 \%$ & $0.0283 \%$ \\
\hline Swap contracts & $0.4242 \%$ & $0.5135 \%$ & $0.2257 \%$ & $0.1220 \%$ & $0.3022 \%$ & $0.1913 \%$ & $0.0759 \%$ & $0.0532 \%$ & $0.0621 \%$ \\
\hline Other derivatives & $0.0117 \%$ & $0.0118 \%$ & $0.1342 \%$ & $0.0134 \%$ & $0.0367 \%$ & $0.0105 \%$ & $0.0278 \%$ & $0.0069 \%$ & $0.0079 \%$ \\
\hline
\end{tabular}

In turn, when analysing the role of passive derivatives as sources of financing for enterprises, their importance is negligible and decreased over the examined period. In 2010, it was $0.93 \%$ and decreased to reach the level of $0.54 \%$ in 2017 . When considering the types of derivatives, under liabilities, in the initial period of analysis, swap contracts dominated ( $0.42 \%$ in $2010,0.51 \%$ in 2011). This means that, in the covered period, swaps caused a negative valuation in a larger number of non-financial enterprises. At the beginning of the discussed period, options were also a significant part of passive financial instruments (enterprises as option writers). Their share in 2010 was $0.37 \%$, and in 2011 it decreased to the level of $0.16 \%$.

After 2013, the most frequently used derivatives were forward contracts - they stood at around the level of $0.3 \%$. 


\section{Conclusions}

The purpose of this article was to determine whether financialization phenomena affected the financing structure of non-financial enterprises operating in Poland. The conducted research allows to state that this phenomenon is not noticeable in the example of the examined economic entities.

The share of foreign capital in the total liabilities of enterprises in 2010-2018 was around the level of 0.5 . This means that half of the enterprise's assets were financed by foreign sources of financing. In the financial assessment, it is the optimal financing structure that does not characterise the phenomenon of enterprise finalisation. While analysing the sectors in terms of financing structure, it is also impossible to indicate the industry that would be characterised by the manifestations of the processes of financing liabilities.

When considering passive financial instruments, their role increased over the examined period. In the years 2010-2013, this indicator was at the level of $10 \%-14 \%$, while after 2014 it increased to the level of $20 \%$. The reason for this increase was the growing importance of credits and loans. In the discussed period, the importance of debt financial securities (bonds) as sources of financing for enterprises also increased, however the share of these instruments in total liabilities is low (in 2015, the highest level was 6.8\%). In turn, when analysing the role of passive derivatives, their importance in total liabilities was negligible and did not exceed $1 \%$ (the maximum level in 2011 was $0.97 \%$, in subsequent years it decreased). Thus, both the level and structure of passive financial instruments do not show the features of the phenomenon of financialization of the enterprise financing structure.

Financialization is a developing phenomenon. The presented research covered the years 2010-2018, therefore research on the discussed issue should be continued. Further considerations can also be expanded to include international comparisons.

\section{Acknowledgements}

This paper was financed from the resources of the Silesian University of Technology, project no. BK-235/ROZ-1/2020 (13/010/BK_20/0042). 


\section{References}

1. BIS. Retrieved from https://www.bis.org/statistics/about_derivatives_stats.htm?m= 6\%7C32\%7C639, 15.09.2019.

2. Crotty, J. (2005). The Neoliberal Paradox: The Impact of Destructive Product Market Competition and Modern Financial Markets on Nonfinancial Corporation Performance in the Neoliberal Era. In: G.A. Epstein (Ed.), Financialization and the World Economy. Northampton: Edward Elgar Publishing.

3. Dembiński, P.H. (2011). Finanse po zawale. Od euforii finansowej do gospodarczego ładu. Warszawa: Studio Emka.

4. EURIBOR-RATES.EU. Retrieved from http://www.euribor-rates.eu/euribor-rate-12months, 15.09.2019.

5. Froud, J., Haslam, C., Johal, S., Williams, K. (2000). Shareholder value and financialization; consultancy promises, management moves. Economy and Society, 29(1), doi: 10.1080/030851400360578.

6. Gmytrasiewicz, M., Karmańska, A. (2010). Rachunkowośc finansowa. Difin.

7. Instrumenty finansowe przedsiębiorstw niefinansowych. Za lata 2010-2018. Warszawa: GUS, Retrieved from http://stat.gov.pl/obszary-tematyczne/podmioty-gospodarczewyniki-finansowe/przedsiebiorstwa-niefinansowe/instrumenty-finansoweprzedsiebiorstw-niefinansowych,20,3.html, 15.09.2019.

8. Jonek-Kowalska, I., Zieliński, M. (2017). CSR activities in the banking sector in Poland. Proceedings of the 29th International Business Information Management Association Conference - Education Excellence and Innovation Management through Vision 2020: From Regional Development Sustainability to Global Economic Growth.

9. Milberg, W., Shifting sources and uses of profits: sustaining US financialization with global value chains. Economy and Society, 37. doi: 10.1080/03085140802172706.

10. Nawrocki, T.L., Szwajca, D. (2016). The Concept of Corporate Reputation Assessment Model - the Stock Market Investors Perspective. In: A. Kavoura, D.P. Sakas, P. Tomaras (Eds.), Strategic Innovative Marketing. Springer Proceedings in Business and Economics.

11. Ratajczak, M. (2012). Financialization of the economy. Ekonomista, 3.

12. Rydzewska, A. (2016). Contemporary Nature of Stock Exchange in View of the Process of Demutualization. Oeconomia Copernicana, 7(1), doi: 10.12775/OeC.2016.004.

13. Rydzewska, A. (2019). The significance of derivatives in the management of value of nonfinancial enterprises in Poland in the age of financialization. In: G. Dukic, J. Clifford, D. Atkinson (Eds.), Economic and Social Development. 42nd International Scientific Conference on Economic and Social Development, Book of Proceedings, London.

14. Sierpińska, M.T. (2004). Jachna, Ocena przedsiębiorstw wedlug standardów światowych. Warszawa: PWN. 
15. Stockhammer, E. (2004). Financialization and the slowdown of accumulation. Cambridge Journal Of Economics, 28(5). doi: 10.1093/cje/beh032.

16. Szczepankowski, P. (2016). Finansyzacja przedsiębiorstw przemysłowych w Polsce. Kwartalnik Nauk o Przedsiębiorstwie, 38(1).

17. Szczepankowski, P. (2017), Financialization of the non-financial corporations and enterprise value migration. Evidence from the polish stock market: 2000-2015. Studia i Prace WNEiZ US, 50(3), doi: 10.18276/sip.2017.50/3-13.

18. Williams, K. (2000). From Shareholder Value to Present-day Capitalism, Economy And Society, 29(1), doi: 10.1080/030851400360532. 